\title{
Interaction of vitamin D with membrane-based signaling pathways
}

\author{
María Jesús Larriba ${ }^{1}$, José Manuel González-Sancho ${ }^{1}$, Félix Bonilla ${ }^{2}$ and Alberto Muñoz ${ }^{1 *}$ \\ 1 Instituto de Investigaciones Biomédicas "Alberto Sols," Consejo Superior de Investigaciones Científicas, Universidad Autónoma de Madrid, Madrid, Spain \\ 2 Department of Medical Oncology, Hospital Universitario Puerta de Hierro Majadahonda, Majadahonda, Spain
}

\section{Edited by: \\ Carsten Carlberg, University of \\ Eastern Finland, Finland}

Reviewed by:

Enikö Kallay, Medical University of Vienna, Austria

Johannes Van Leeuwen, Erasmus

$M C$, Netherlands

${ }^{*}$ Correspondence:

Alberto Muñoz, Instituto de

Investigaciones Biomédicas "Alberto

Sols," Consejo Superior de

Investigaciones Científicas,

Universidad Autónoma de Madrid,

Arturo Duperier 4, E-28029 Madrid,

Spain

e-mail:amunoz@iib.uam.es
Many studies in different biological systems have revealed that $1 \alpha, 25$-dihydroxyvitamin $\mathrm{D}_{3}\left(1 \alpha, 25(\mathrm{OH})_{2} \mathrm{D}_{3}\right)$ modulates signaling pathways triggered at the plasma membrane by agents such as Wnt, transforming growth factor (TGF)- $\boldsymbol{\beta}$, epidermal growth factor (EGF), and others. In addition, $1 \alpha, 25(\mathrm{OH})_{2} \mathrm{D}_{3}$ may affect gene expression by paracrine mechanisms that involve the regulation of cytokine or growth factor secretion by neighboring cells. Moreover, post-transcriptional and post-translational effects of $1 \alpha, 25(\mathrm{OH})_{2} \mathrm{D}_{3}$ add to or overlap with its classical modulation of gene transcription rate. Together, these findings show that vitamin $\mathrm{D}$ receptor (VDR) cannot be considered only as a nuclear-acting, ligand-modulated transcription factor that binds to and controls the transcription of target genes. Instead, available data support the view that much of the complex biological activity of $1 \alpha, 25(\mathrm{OH})_{2} \mathrm{D}_{3}$ resides in its capacity to interact with membrane-based signaling pathways and to modulate the expression and secretion of paracrine factors. Therefore, we propose that future research in the vitamin $D$ field should focus on the interplay between $1 \alpha, 25(\mathrm{OH})_{2} \mathrm{D}_{3}$ and agents that act at the plasma membrane, and on the analysis of intercellular communication. Global analyses such as RNA-Seq, transcriptomic arrays, and genome-wide ChIP are expected to dissect the interactions at the gene and molecular levels.

Keywords: $1 \alpha, 25(\mathrm{OH})_{2} \mathrm{D}_{3}, \mathrm{VDR}$, membrane-based signaling, Wnt, growth factors, cytokines, paracrine effects

\section{INTRODUCTION}

The active vitamin $\mathrm{D}$ metabolite $1 \alpha, 25$-dihydroxyvitamin $\mathrm{D}_{3}$ $\left(1 \alpha, 25(\mathrm{OH})_{2} \mathrm{D}_{3}\right)$ is a key regulator of gene expression in higher organisms. It modulates the activity of the vitamin $\mathrm{D}$ receptor (VDR), a member of the superfamily of nuclear hormone receptors that regulate gene transcription. Genome-wide chromatin immunoprecipitation studies have shown that VDR binds to hundreds of genome sites even in the absence of $1 \alpha, 25(\mathrm{OH})_{2} \mathrm{D}_{3}$ and that ligand binding increases and partially changes these binding sites, which depend on the cell type and the duration of treatment (Carlberg and Campbell, 2013). While a subset of VDR binding sites may be responsible for the control of gene expression (VDREs or vitamin D response elements), others might be temporary anchorage places for a population of unliganded "dormant" VDR. According to the classical view, VDR binds DNA as heterodimers with a retinoid $\mathrm{X}$ receptor $(\mathrm{RXR} \alpha, \beta$, or $\gamma$ ) and, upon ligand binding, changes the transcription rate of neighboring genes.

However, many genes whose expression is altered by $1 \alpha, 25(\mathrm{OH})_{2} \mathrm{D}_{3}$ do not contain VDREs. Putative mechanisms of this action include post-transcriptional regulation via changes in the levels of microRNAs that modulate the half-life and/or translation of their messenger RNAs (Thorne et al., 2011; Wang et al., 2011; Alvarez-Díaz et al., 2012; Kasiappan et al., 2012; Guan et al., 2013). Also, $1 \alpha, 25(\mathrm{OH})_{2} \mathrm{D}_{3}$ may regulate genes post-translationally via changes in the phosphorylation or other modifications of proteins which affect their stability (Lin et al., 2003; Li et al., 2004), or through changes in the level or activity of proteases that target them (Alvarez-Díaz et al., 2010).

Increasing importance has recently been accorded to another mechanism of $1 \alpha, 25(\mathrm{OH})_{2} \mathrm{D}_{3}$ action: the modulation of signaling pathways triggered by other agents at the plasma membrane. Indeed, a number of studies have shown that $1 \alpha, 25(\mathrm{OH})_{2} \mathrm{D}_{3}$ modulates the effects of growth factors and cytokines by altering either their cytosolic signaling pathways or the activity of target transcription factors in the nucleus, or even in a paracrine fashion by inhibiting their synthesis and secretion by neighboring cells.

Here we review the available data on these non-classical, alternative mechanisms by which $1 \alpha, 25(\mathrm{OH})_{2} \mathrm{D}_{3}$ modulates gene expression. Notably, for specific genes such as c-MYC, both direct transcriptional and indirect modes of regulation by $1 \alpha, 25(\mathrm{OH})_{2} \mathrm{D}_{3}$ have been described (Pan and Simpson, 1999; Pálmer et al., 2001; Toropainen et al., 2010; Salehi-Tabar et al., 2012).

\section{INTERACTION OF $1 \alpha, 25(\mathrm{OH})_{2} \mathrm{D}_{3}$ WITH WNT, HEDGEHOG, AND NOTCH PATHWAYS}

Wnt, Hedgehog, and Notch signaling pathways, which have long been known to play crucial roles during development, are now considered critical for many tumorigenic processes in which they function abnormally due to mutation and/or changes in expression of components. 
Wnt factors activate several signaling pathways upon binding to different plasma membrane receptors: the canonical or Wnt/ $\beta$-catenin and the non-canonical (planar polarity, $\mathrm{Ca}^{2+} \ldots$ ) pathways (Clevers and Nusse, 2012). Activation of the Wnt/ $\beta$-catenin pathway by mutation of $A P C$ or $A X I N$ tumor suppressor genes or of $C T N N B 1 / \beta$-catenin oncogene together with changes in the expression of a number of regulatory genes (SFRPs, DICKKOPF (DKK)s...) is a hallmark of most colorectal cancers and of a variable proportion of several other malignancies (Clevers and Nusse, 2012). A series of studies report that $1 \alpha, 25(\mathrm{OH})_{2} \mathrm{D}_{3}$ antagonizes $\mathrm{Wnt} / \beta$-catenin signaling in colon cancer cells by several mechanisms: the reduction of transcriptionally active $\beta$-catenin/T-cell factor complexes, the induction of $\beta$-catenin relocation from the nucleus toward the adherens junctions structures at the plasma membrane, and the increase in the level of the Wnt inhibitor DKK-1 (Pálmer et al., 2001; Shah et al., 2006; Aguilera et al., 2007) (Figure 1). In this way, the pathway endpoint, i.e., the activation of $\beta$-catenin target genes, is attenuated by $1 \alpha, 25(\mathrm{OH})_{2} \mathrm{D}_{3}$ (Pálmer et al., 2001). Emphasizing the importance of this action, an additional indirect mechanism of Wnt $/ \beta$-catenin antagonism in colon cancer has been proposed involving IL-1 $\beta$, which will be reviewed in section $1 \alpha, 25(\mathrm{OH})_{2} \mathrm{D}_{3}$ and Cytokines. Although $1,25(\mathrm{OH})_{2} \mathrm{D}_{3}$ inhibits $\beta$-catenin/TCF transcriptional activity in colon and other cancer cells, the upregulation of the Wnt/ $\beta$-catenin pathway by either ligand-activated or unliganded VDR has been described in osteoblasts and keratinocytes, where it promotes bone formation and hair follicle differentiation, respectively (Larriba et al., 2013). However, the results reported in keratinocytes are controversial: while VDR enhances Wnt signaling through direct binding to Lymphocyte Enhancer-binding Factor (LEF)-1 independently of ligand and $\beta$ catenin (Luderer et al., 2011), ligand-activated VDR is believed to inhibit Wnt/ $\beta$-catenin signaling (Bikle, 2011; Jiang et al., 2012).

Inhibition of Hedgehog $(\mathrm{Hh})$ signaling by vitamin $\mathrm{D}$ compounds has also been suggested. In a study combining experiments in zebrafish, the yeast Pichia pastori and mouse fibroblasts, secreted vitamin $\mathrm{D}_{3}$, or its precursor 7-dehydrocholesterol (7-DHC), was shown to mediate the paracrine inhibition of Smoothened (Smo) by Patched (Ptch)1 which leads to pathway inactivation (Bijlsma et al., 2006). In the model proposed, which includes the binding of vitamin $\mathrm{D}_{3}$ to Smo at high (micromolar) concentrations, Hh ligands activate the pathway by blocking the induction of the secretion of vitamin $\mathrm{D}_{3} / 7-\mathrm{DHC}$ by Ptch 1 (Bijlsma et al., 2006) (Figure 1). The Hh pathway is aberrantly activated in basal cell carcinoma, the most frequent human tumor type. Interestingly, $1 \alpha, 25(\mathrm{OH})_{2} \mathrm{D}_{3}$ inhibits proliferation and induces differentiation of mouse basal cell carcinomas and embryonal rhabdomyosarcomas with an activated $\mathrm{Hh}$ pathway due to Ptch1 deletion (Uhmann et al., 2011, 2012). As in the previous study, $1 \alpha, 25(\mathrm{OH})_{2} \mathrm{D}_{3}$ acts at the level of Smo in a VDRindependent manner (Figure 1). Curiously, Tang et al. found that vitamin $\mathrm{D}_{3}$ inhibits $\mathrm{Hh}$ and cell proliferation more effectively than 7-DHC, $25(\mathrm{OH}) \mathrm{D}_{3}$, or $1 \alpha, 25(\mathrm{OH})_{2} \mathrm{D}_{3}$ in murine basal cell carcinoma cells (Tang et al., 2011). Vitamin $\mathrm{D}_{3}$ also inhibits proliferation and $\mathrm{Hh}$ pathway through inactivation of Smo in cultured mouse pancreatic adenocarcinoma cells, but has no antitumor activity in vivo (Brüggemann et al., 2010). A common concern in all these studies is the high concentration of vitamin $D_{3}$ required to observe the reported effects. Research in $V d r$-deficient mice and in mouse skin explants has shown that lack of VDR increases the expression of several components of the Hh pathway such as Shh, Smo, Gli1, Gli2, and Ptch1, while $1 \alpha, 25(\mathrm{OH})_{2} \mathrm{D}_{3}$ suppresses their expression (Bikle et al., 2013) (Figure 1). However, the interaction between $1 \alpha, 25(\mathrm{OH})_{2} \mathrm{D}_{3}$ and Hh signaling in human skin remains to be elucidated.

Few studies link vitamin D with Notch signaling. Differentiation of human osteoblasts with vitamin $\mathrm{D}_{3}$ and dexamethasone distinctly affects the expression of Notch receptor family members (Schnabel et al., 2002). In rodent osteoblasts, the transcription factor Hes-1, which is an effector of the Notch pathway, enhances the induction of SPP1/osteopontin transcription by $1 \alpha, 25(\mathrm{OH})_{2} \mathrm{D}_{3}$, indicating the collaboration of $1 \alpha, 25(\mathrm{OH})_{2} \mathrm{D}_{3}$ and Notch pathways in bone remodeling (Shen and Christakos, 2005) (Figure 1). Transcriptomic analyses in human RWPE1 immortalized non-tumorigenic prostate cells showed the reduction of the RNA levels of the NOTCH ligands JAGGED (JAG)1, JAG2, and Delta-like (DLL) 1 by $1 \alpha, 25(\mathrm{OH})_{2} \mathrm{D}_{3}$ (Kovalenko et al., 2010) (Figure 1). By contrast, no changes in the expression of NOTCH-1 and JAG1 were detected in cultured human keratinocytes upon $1 \alpha, 25(\mathrm{OH})_{2} \mathrm{D}_{3}$ treatment (Reichrath and Reichrath, 2012). As JAG1 transcription and, consequently, Notch signaling are upregulated by Wnt/ $\beta$-catenin in colorectal cancer cells (Rodilla et al., 2009), the repressive effect of $1 \alpha, 25(\mathrm{OH})_{2} \mathrm{D}_{3}$ on the Notch pathway in this system may be secondary to the antagonism of the $\mathrm{Wnt} / \beta$-catenin pathway (Figure 1).

\section{INTERPLAY OF $1 \alpha, 25(\mathrm{OH})_{2} \mathrm{D}_{3}$ WITH AGENTS THAT TRIGGER SIGNALING PATHWAYS VIA PLASMA MEMBRANE KINASE RECEPTORS}

There is mutual antagonism between $1 \alpha, 25(\mathrm{OH})_{2} \mathrm{D}_{3}$ and epidermal growth factor (EGF), a potent mitogen, in primary colon epithelial cells and in established colon (Caco-2) and breast (T47D) tumor cell lines. This is based on the cross-inhibition of the expression of their respective receptors, VDR and EGFR (Tong et al., 1998, 1999). However, it is a cell type-dependent effect as EGF increases VDR in the rat small intestine and $1 \alpha, 25(\mathrm{OH})_{2} \mathrm{D}_{3}$ increases EGFR in BT-20 breast cancer cells (Bruns et al., 1989; Desprez et al., 1991). In addition, $1 \alpha, 25(\mathrm{OH})_{2} \mathrm{D}_{3}$ inhibits EGFR signaling by increasing the level of E-cadherin protein at the plasma membrane, which downregulates EGFR (Pálmer et al., 2001; Andl and Rustgi, 2005), and by decreasing that of SPROUTY-2, a cytosolic protein that reduces EGFR ubiquitination, internalization and degradation (Cabrita and Christofori, 2008; Barbáchano et al., 2010).

Transforming growth factor (TGF)- $\beta$ has opposite roles in carcinogenesis: it inhibits proliferation of normal epithelial cells, but it later induces epithelial-mesenchymal transition, immunosuppression and metastasis (Pickup et al., 2013). $1 \alpha, 25(\mathrm{OH})_{2} \mathrm{D}_{3}$ induces the expression of the type I TGF- $\beta$ receptor and both agents, $1 \alpha, 25(\mathrm{OH})_{2} \mathrm{D}_{3}$ and TGF- $\beta$, cooperate in Caco- 2 cell growth inhibition (Chen et al., 2002; Pálmer et al., 2003). Moreover, Smad3, a mediator of TGF- $\beta$ signaling, is a co-activator of VDR and contributes to gene regulation by $1 \alpha, 25(\mathrm{OH})_{2} \mathrm{D}_{3}$ 


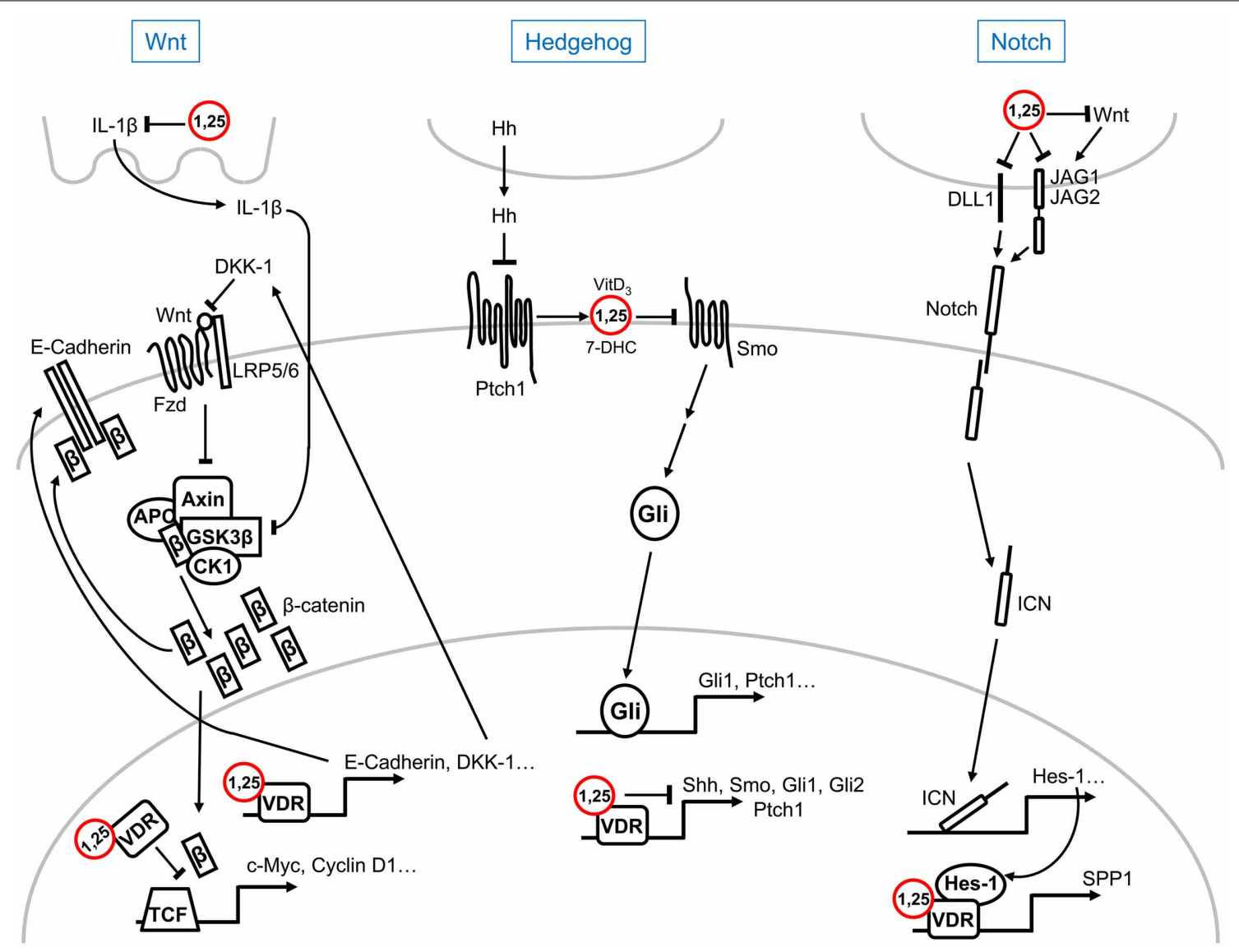

FIGURE 1 | Schematic representation of the multilevel crosstalk of $1 \alpha, 25(\mathrm{OH})_{2} \mathrm{D}_{3}(\mathbf{1 , 2 5 )}$ with Wnt, Hedgehog, and Notch signaling pathways. For simplicity, only main components and regulators of the pathways are shown. Explanations, details, and references can be found in the text.

(Yanagisawa et al., 1999), an effect that is abrogated by Smad7 in transfected COS-7 cells (Yanagi et al., 1999). Reinforcing the interaction between both signaling pathways, $1 \alpha, 25(\mathrm{OH})_{2} \mathrm{D}_{3}$ induces the expression of Smad anchor for receptor activation (SARA) (Pálmer et al., 2003), which maintains the epithelial phenotype by recruiting Smads $2 / 3$ to the activated TGF- $\beta$ receptors and regulates endocytic trafficking of EGFR and other proteins (Tang et al., 2011; Kostaras et al., 2013). Notably, a recent study of R. M. Evans' group has revealed a genome-wide overlap of VDR and Smad3 binding sites that is responsible for the abrogation by VDR ligands of the TGF- $\beta 1$-mediated activation of hepatic stellate cells during liver fibrosis (Ding et al., 2013). These authors show that TGF- $\beta 1$ signaling redistributes VDR-binding sites in the genome and facilitates VDR binding at Smad3 profibrotic target genes. Upon ligand activation, VDR binding at coregulated genes decreases Smad3 occupancy at these sites, causing inhibition of fibrosis (Ding et al., 2013). This is a regulatory feedback mechanism in which VDR ligands limit the fibrotic process and so ensure an appropriate non-pathological tissue response. Given the crucial roles of TGF- $\beta$ in carcinogenesis, future studies should examine whether vitamin D compounds play similar roles in the maintenance of epithelial integrity opposing the onset of carcinomas.
$1 \alpha, 25(\mathrm{OH})_{2} \mathrm{D}_{3}$ and TGF- $\beta$ interact also in bone. Curiously, in rat (UMR 106 and ROS 17/2.8) and human (MG-63) osteoblastic cells TGF- $\beta$ increases VDR expression but inhibits the stimulation of osteocalcin and osteopontin transcription and RNA levels by $1 \alpha, 25(\mathrm{OH})_{2} \mathrm{D}_{3}$ (Staal et al., 1994). TGF- $\beta$ exerts this inhibitory effect by reducing the binding of VDR-RXR complexes to VDREs localized in the promoter of these genes without affecting the nuclear availability of VDR at least in ROS $17 / 2.8$ cells (Staal et al., 1996). In contrast to the stimulation of osteocalcin synthesis in human and rat cells, $1 \alpha, 25(\mathrm{OH})_{2} \mathrm{D}_{3}$ decreases osteocalcin production in mouse fetal long bone cultures and neonatal osteoblastic MC3T3 cells while stimulating bone resorption (Staal et al., 1998). This bone resorption action of $1 \alpha, 25(\mathrm{OH})_{2} \mathrm{D}_{3}$ is dose-dependently inhibited by TGF- $\beta$ (Staal et al., 1998).

A complex, cell type-, context- and sometimes age-dependent relation exists between $1 \alpha, 25(\mathrm{OH})_{2} \mathrm{D}_{3}$ and insulin-like growth factors (IGF)-I and II. For instance, in $\mathrm{C} 2 \mathrm{C} 12$ myoblasts $1 \alpha, 25(\mathrm{OH})_{2} \mathrm{D}_{3}$ decreases IGF-I expression while it increases that of IGF-II (Garcia et al., 2011). In HT29 colon carcinoma cells several vitamin D compounds inhibit the secretion of IGF-II thus attenuating its cell proliferation activity (Oh et al., 2001). In addition, $1 \alpha, 25(\mathrm{OH})_{2} \mathrm{D}_{3}$ blocks the mitogenic activity of insulin 
and IGF-I in MCF7 breast cancer cells, at least in part due to the inhibition of c-FOS upregulation (Vink-van Wijngaarden et al., 1996). $1 \alpha, 25(\mathrm{OH})_{2} \mathrm{D}_{3}$ and IGF-I have also opposite effects on mouse long bones: IGF-I increases osteocalcin production, which is completely blocked by $1 \alpha, 25(\mathrm{OH})_{2} \mathrm{D}_{3}$, and inhibits the enhancement of bone resorption caused by $1 \alpha, 25(\mathrm{OH})_{2} \mathrm{D}_{3}$ (Staal et al., 1998). Furthermore, $1 \alpha, 25(\mathrm{OH})_{2} \mathrm{D}_{3}$ variably regulates the expression of several IGF binding proteins (IGFBPs), a group of molecules with pleiotropic actions that transport IGFs and also modulate cell survival/apoptosis: $1 \alpha, 25(\mathrm{OH})_{2} \mathrm{D}_{3}$ induces IGFBP3 expression in SW480-ADH colon carcinoma, SaOS-2 osteosarcoma, PC3 prostate cancer, MCF7 breast carcinoma and MCF-10A normal mammary cells (Pálmer et al., 2003; Matilainen et al., 2005; Malinen et al., 2011; Brosseau et al., 2013), IGFBP6 in SaOS-2, SW480-ADH and colon carcinoma HT29 cells (Oh et al., 2001; Pálmer et al., 2003; Matilainen et al., 2005), IGFBP1 and IGFBP5 in SaOS-2 and PC3 cells, and IGFBP4 in SaOS-2 cells (Matilainen et al., 2005). Conversely, $1 \alpha, 25(\mathrm{OH})_{2} \mathrm{D}_{3}$ represses IGFBP4 in HT29 and SW480-ADH cells, and IGFBP2 in HT29 cells (Oh et al., 2001; Pálmer et al., 2003). In ovarian cells, $1 \alpha, 25(\mathrm{OH})_{2} \mathrm{D}_{3}$ alone induces IGFBP1 production but, conversely, it enhances the inhibitory effect of insulin (Parikh et al., 2010). Curiously, recent studies show that IGFBP3 interacts with VDR (Li et al., 2013) and that IGFBP6 binds VDR and blocks the induction of osteoblast differentiation by $1 \alpha, 25(\mathrm{OH})_{2} \mathrm{D}_{3}$ (Cui et al., 2011).

Cell type-dependent effects of $1 \alpha, 25(\mathrm{OH})_{2} \mathrm{D}_{3}$ have also been described for hepatocyte growth factor (HGF) signaling. $1 \alpha, 25(\mathrm{OH})_{2} \mathrm{D}_{3}$ activates the $H G F$ gene promoter and induces HGF expression and secretion in rat NRK-49F renal interstitial fibroblasts (Li et al., 2005) and in human keloid fibroblasts (Zhang et al., 2011). Consistently with these results, vitamin D deficiency reduces HGF and HGF receptor/c-Met expression during liver regeneration in rats (Goupil et al., 1997). Conversely, $1 \alpha, 25(\mathrm{OH})_{2} \mathrm{D}_{3}$ decreases the level of HGF RNA in human HL-60 promyelocitic leukemia cells (Inaba et al., 1993), smooth muscle cells (Shalhoub et al., 2010) and MG-63 osteosarcoma cells (Chattopadhyay et al., 2003). Moreover, the expression of c-Met is inhibited by $1 \alpha, 25(\mathrm{OH})_{2} \mathrm{D}_{3}$ in human MHCC97 hepatocellular cell line (Wu et al., 2007). Curiously, $1 \alpha, 25(\mathrm{OH})_{2} \mathrm{D}_{3}$ and HGF cooperate to increase osteogenic differentiation of human bone marrow stem cells and maturation of chondrocyte progenitor cells (Grumbles et al., 1996; D'Ippolito et al., 2002; Chen et al., $2011,2012)$. Also, $1 \alpha, 25(\mathrm{OH})_{2} \mathrm{D}_{3}$ and HGF additively inhibit proliferation of androgen-unresponsive prostate cancer cells (Qadan et al., 2000).

In concordance with its regulatory role in the organism, $1 \alpha, 25(\mathrm{OH})_{2} \mathrm{D}_{3}$ favors physiological and homeostatic angiogenesis but inhibits angiogenesis in pathological conditions. Thus, $1 \alpha, 25(\mathrm{OH})_{2} \mathrm{D}_{3}$ promotes myogenic differentiation of $\mathrm{C} 2 \mathrm{C} 12$ cells by increasing the expression of two key angiogenic factors: vascular endothelial growth factor (VEGF) and fibroblast growth factor-1 (Garcia et al., 2013). In addition, $1 \alpha, 25(\mathrm{OH})_{2} \mathrm{D}_{3}$ stimulates pro-angiogenic properties of endothelial progenitor cells by increasing VEGF levels (Grundmann et al., 2012). $1 \alpha, 25(\mathrm{OH})_{2} \mathrm{D}_{3}$ also upregulates VEGF expression in osteoblast-like cells but not in breast cancer cells (Schlaeppi et al., 1997). Likewise, ED-71, a vitamin D analog, enhances VEGF expression and promotes angiogenesis in a murine bone marrow ablation model (Okuda et al., 2007). Indeed, increased production of VEGF in vascular smooth muscle cells results from the activation of a VDRE present in the VEGF gene promoter (Cardus et al., 2009). By contrast, $1 \alpha, 25(\mathrm{OH})_{2} \mathrm{D}_{3}$ downregulates hypoxia-inducible factor (HIF)-1 and VEGF protein expression in several human colon, prostate and breast cancer cell lines (Ben-Shoshan et al., 2007), decreases VEGF production by human lumbar annulus cells (Gruber et al., 2008), and protects against diabetic retinopathy in rats by inhibiting VEGF expression in the retina (Ren et al., 2012).

$1 \alpha, 25(\mathrm{OH})_{2} \mathrm{D}_{3}$ also modulates the activity of signaling pathways mediated by other types of plasma membrane receptors such us $G$ protein-coupled receptors. Shen et al. found that $1 \alpha, 25(\mathrm{OH})_{2} \mathrm{D}_{3}$ suppresses the expression of parathyroid hormone-related protein (PTHrP) in prostate cancer cells via a negative VDRE localized within the non-coding region of the gene, thus antagonizing the induction of cell proliferation and of the expression of the pro-invasive integrin $\alpha_{6} \beta_{4}$ exerted by PTHrP signaling (Shen et al., 2007).

\section{$1 \alpha, 25(\mathrm{OH})_{2} \mathrm{D}_{3}$ AND CYTOKINES}

The anti-inflammatory and immunomodulatory actions, and thus some of the anticancer and antimicrobial effects of $1 \alpha, 25(\mathrm{OH})_{2} \mathrm{D}_{3}$, are mediated by the regulation of cytokine production and/or through the control of their receptors or downstream signaling pathways. Globally, $1 \alpha, 25(\mathrm{OH})_{2} \mathrm{D}_{3}$ contributes to the autocrine and paracrine control of innate and adaptative immune responses (Adorini and Penna, 2008).

$1 \alpha, 25(\mathrm{OH})_{2} \mathrm{D}_{3}$ regulates the function of antigen-presenting cells and T-lymphocytes. It inhibits Th1 cells differentiation and, therefore, the secretion of Th1-type cytokines, enhances the development of Th2 cells, and induces tolerogenic monocytes and dendritic cells. IL-4 and IL-10 are among the commonly increased cytokines, while IL-1, IL-2, IL-6, IL-17, tumor necrosis factor (TNF) $-\alpha$ and interferon (IFN) $-\gamma$ are decreased (Adorini and Penna, 2008).

Mechanistically, ligand-activated VDR directly downregulates the expression of IL-10, IL-2, and IL-12B in lipopolysaccharidetreated human monocytes (THP-1) through its binding to VDREs located in the genomic regions of these genes and the recruitment of the co-repressor NCOR/SMRT and histone deacetylases (Matilainen et al., 2010a,b; Gynther et al., 2011). Remarkably, IL10 is downregulated by short $1 \alpha, 25(\mathrm{OH})_{2} \mathrm{D}_{3}$ treatment $(8 \mathrm{~h})$ but upregulated at late time points ( $48 \mathrm{~h}$ ) (Matilainen et al., 2010a). In addition, direct VDR binding to a single VDRE mediates the upregulation of $I L-8$ gene by $1 \alpha, 25(\mathrm{OH})_{2} \mathrm{D}_{3}$ in undifferentiated and differentiated THP-1 cells (Ryynänen and Carlberg, 2013).

$1 \alpha, 25(\mathrm{OH})_{2} \mathrm{D}_{3}$ also changes the expression of target genes in immune cells by repressing crucial transcription factors such as nuclear factor kappa $\mathrm{B}(\mathrm{NFkB})$ and signaling pathways such as Janus kinase-signal transducer and activator of transcription (JAK-STAT) (Yu et al., 1995; Muthian et al., 2006; Geldmeyer-

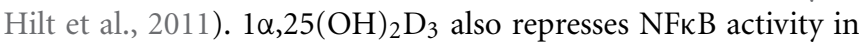
fibroblasts and adipocytes (Harant et al., 1998; Mutt et al., 2012), and fibroblasts lacking VDR have increased NFKB activity (Sun et al., 2006). Direct (increase in I $\mathrm{B} \alpha \alpha$ expression and reduction 
of nuclear translocation of p65) and indirect (upregulation of IGFBP3 and clusterin) mechanisms contribute to the inhibition of NFKB activation (Krishnan and Feldman, 2010). D. Feldman's group has reported that, in addition to inhibiting $\mathrm{NF \kappa B}$, the antiinflammatory effects of $1 \alpha, 25(\mathrm{OH})_{2} \mathrm{D}_{3}$ in prostate cancer cells include the reduction of pro-inflammatory prostaglandins (PG) production via suppression of ciclooxygenase-2, downregulation of PG receptors, and upregulation of 15-hydroxyprostaglandin dehydrogenase, which inactivates PGs (Krishnan and Feldman, 2010). Moreover, $1 \alpha, 25(\mathrm{OH})_{2} \mathrm{D}_{3}$ decreases the synthesis of proinflammatory IL- 6 through the inactivation of p38 kinase due to the upregulation of the mitogen kinase phosphatase (MKP) 5 and the blockade of TNF- $\alpha$ (Krishnan and Feldman, 2010). In Jurkat cells, the repression of $I L-2$ gene by $1 \alpha, 25(\mathrm{OH})_{2} \mathrm{D}_{3}$ is at least partially due to the blockade of NFATp/AP-1 complex formation at a positive regulatory NFAT-1 site, which is bound by VDR-RXR heterodimers (Alroy et al., 1995).

$1 \alpha, 25(\mathrm{OH})_{2} \mathrm{D}_{3}$ reduces the secretion of interleukin (IL) $1-\beta$ in THP macrophages by blocking the activation of STAT1 (Kaler et al., 2009). As IL1- $\beta$ activates the $W n t / \beta$-catenin pathway in colon carcinoma cells via inhibition of GSK3 $\beta$ activity and subsequent stabilization and nuclear translocation of $\beta$-catenin, this mechanism may contribute to the antagonism of Wnt signaling by $1 \alpha, 25(\mathrm{OH})_{2} \mathrm{D}_{3}$ (Kaler et al., 2009) (Figure 1). Curiously, IL- $1 \alpha$ is believed to be upregulated and to mediate the antiproliferative effects of $1 \alpha, 25(\mathrm{OH})_{2} \mathrm{D}_{3}$ in prostate progenitor/stem cells (Maund et al., 2011).

In human osteoblasts, $1 \alpha, 25(\mathrm{OH})_{2} \mathrm{D}_{3}$ completely overrules the inhibitory effect of IFN- $\beta$ on mineralization. This dominant effect on osteoblast differentiation and bone formation is reflected in the downregulation of IFN-related and -regulated genes by $1 \alpha, 25(\mathrm{OH})_{2} \mathrm{D}_{3}$ (Woeckel et al., 2012). Concomitantly, $1 \alpha, 25(\mathrm{OH})_{2} \mathrm{D}_{3}$ also induces activin $\mathrm{A}$, a strong inhibitor of mineralization, and represses follistatin, the natural antagonist of activin $\mathrm{A}$, to ensure a fine-tuned regulation of the mineralization process (Woeckel et al., 2013b).

Recent findings have underscored the complexity of $1 \alpha, 25(\mathrm{OH})_{2} \mathrm{D}_{3}$ action and its role in the antimicrobial response as part of innate and adaptative immunity. Thus, activation of macrophage Toll-like receptors (TLRs) by intracellular bacteria such as Mycobacterium tuberculosis upregulates $V D R$ and CYP27B1 genes that allow the induction of the antimicrobial peptide cathelicidin by $1 \alpha, 25(\mathrm{OH})_{2} \mathrm{D}_{3}$ (Liu et al., 2006). In monocytes, TLR activation triggers induction of defensin $\beta 4$ (DEFB4) gene requiring the cooperation between IL- $1 \beta$ and $1 \alpha, 25(\mathrm{OH})_{2} \mathrm{D}_{3}$, which is explained by the presence of one VDRE and two IL- $1 \beta$-activatable NFkB sites in the DEFB4 promoter (Liu et al., 2009). In addition, $1 \alpha, 25(\mathrm{OH})_{2} \mathrm{D}_{3}$ is required for the antimicrobial effect of IFN- $\gamma$ in human macrophages (Fabri et al., 2011). Moreover, by inducing the expression of TLR2 and CD14 receptors and cathelicidin, $1 \alpha, 25(\mathrm{OH})_{2} \mathrm{D}_{3}$ mediates the effect of TGF- $\beta$ favoring the response to microbial infection and wound injury by keratinocytes (Schauber et al., 2007). These findings show also unexpected cooperation of $1 \alpha, 25(\mathrm{OH})_{2} \mathrm{D}_{3}$ with agents (IL-1 $\beta$, TGF- $\beta$, IFN- $\gamma$ ) that are antagonistic in other cell types.

\section{INTERPLAY OF $1 \alpha, 25(\mathrm{OH})_{2} \mathrm{D}_{3} /$ VDR WITH TRANSCRIPTION FACTORS}

Liganded or unliganded VDR interacts with or regulates the expression of a number of transcription factors that are downstream effectors of different signaling pathways (Table 1). An interesting example is the upregulation by $1 \alpha, 25(\mathrm{OH})_{2} \mathrm{D}_{3}$ of $C D K N 1 B / p 27^{\mathrm{Kip} 1}$, a cell cycle regulator gene which lacks VDREs. $1 \alpha, 25(\mathrm{OH})_{2} \mathrm{D}_{3}$ was first shown to induce CDKN1B transcription by stimulating the binding of $\mathrm{Sp} 1$ and NF-Y transcription factors to the CDKN1B promoter in the myelomonocytic U937 cell line (Inoue et al., 1999). Later, direct VDR-Sp1 interaction at the promoter $\mathrm{Sp} 1$ sites was described as responsible for this effect (Huang et al., 2004). In addition to the enhancement of transcription, $1 \alpha, 25(\mathrm{OH})_{2} \mathrm{D}_{3}$ increases the stability of $\mathrm{p} 27^{\mathrm{Kip} 1}$ protein by repressing $\mathrm{p} 45^{\mathrm{Skp} 2}$, an F-box protein, through the induction of VDR-Spl complexes that together with histone deacetylase 1 are recruited to $\mathrm{Sp} 1$ sites at the $\mathrm{p} 45^{\mathrm{Skp} 2}$ gene promoter (Lin et al., 2003; Li et al., 2004; Huang and Hung, 2006).

The granulocyte-macrophage colony-stimulating factor (GM-CSF) gene is another example of unusual regulation by $1 \alpha, 25(\mathrm{OH})_{2} \mathrm{D}_{3}$. Ligand-activated VDR represses $G M-C S F$ through a composite DNA element recognized by Jun-Fos heterodimers (AP-1) and nuclear factor of activated T-cells (NFAT) 1 (Towers et al., 1999). In the absence of RXR, VDR binds to c-Jun and stabilizes AP-1 bound to DNA, which outcompetes NFAT1 and decreases GM-CSF transcription. In Caco-2 cells, $1 \alpha, 25(\mathrm{OH})_{2} \mathrm{D}_{3}$ stimulates $\mathrm{AP}-1$ via activation of protein kinase $\mathrm{C}-\alpha$, ERK and JNK leading to cell differentiation (Chen et al., 1999).

Table 1 | Interplay between VDR and other transcription factors.

\begin{tabular}{lll}
\hline Transcription factor & Biological effect & References \\
\hline Sp1/NF-Y & Potentiation & $\begin{array}{l}\text { Inoue et al., 1999; Huang } \\
\text { et al., 2004 }\end{array}$ \\
AP-1/NFAT1 & Repression & Towers et al., 1999 \\
AP-1 & Activation & Chen et al., 1999 \\
CREB & Repression & Yuan et al., 2007 \\
FOXO3a, FOXO4 & Activation & An et al., 2010 \\
p53 & Mutual repression & Stambolsky et al., 2010; \\
& & Chen et al., 2013 \\
PPAR- $\alpha / \delta$ & Activation & Sertznig et al., 2009a,b \\
PPAR- $\gamma$ & Variable & Alimirah et al., 2012; \\
& Variable & Woeckel et al., 2013a \\
RAR & & Jiménez-Lara and \\
& & Aranda, 1999; \\
& & Tavera-Mendoza et al., \\
& & 2006; Anand et al., 2008; \\
& & Ng et al., 2010 \\
ER & Downregulation & Krishnan et al., 2010; \\
AR & Swami et al., 2013 \\
PIT-1 & Crossregulation & Zhao et al., 1999; Ting \\
& et al., 2005 \\
& Downregulation & Seoane and \\
& & Pérez-Fernández, 2006
\end{tabular}


In renal cells, $1 \alpha, 25(\mathrm{OH})_{2} \mathrm{D}_{3}$ suppresses renin gene expression by blocking the cyclic AMP response element (CRE) through direct binding of VDR to CRE-binding protein (CREB) and so, inhibiting the binding of CREB to the CRE (Yuan et al., 2007). By a complex mechanism, $1 \alpha, 25(\mathrm{OH})_{2} \mathrm{D}_{3}$ also regulates several Forkhead box (FOX) transcription factors. Ligandactivated VDR binds FOXO3a and FOXO4 together with their regulators, sirtuin 1 deacetylase and protein phosphatase 1 , inducing deacetylation and dephosphorylation of FOXO proteins, thereby activating these (An et al., 2010). In the case of the p53 tumor suppressor protein a mutual regulation takes place: while mutated p53 interacts physically with VDR and changes VDR-target genes, converting $1 \alpha, 25(\mathrm{OH})_{2} \mathrm{D}_{3}$ from a pro-apoptotic into an anti-apoptotic agent (Stambolsky et al., 2010), $1 \alpha, 25(\mathrm{OH})_{2} \mathrm{D}_{3}$ activates the promoter of $\mathrm{Mdm} 2$ in a p53-dependent fashion promoting the expression of this negative regulator of p53 protein stability and function (Chen et al., 2013).

Multiple interplays between $1 \alpha, 25(\mathrm{OH})_{2} \mathrm{D}_{3} / \mathrm{VDR}$ and other nuclear receptor ligands have been described. Among them, crosstalk between liganded VDR and peroxisome proliferatoractivated receptor (PPAR) $-\alpha / \delta$ in melanoma cells (Sertznig et al., $2009 a, b)$ that may involve the stimulation of PPAR- $\delta$ expression by $1 \alpha, 25(\mathrm{OH})_{2} \mathrm{D}_{3}$ (Dunlop et al., 2005). A synergistic action of $1 \alpha, 25(\mathrm{OH})_{2} \mathrm{D}_{3}$ and rosiglitazone, a PPAR- $\gamma$ ligand, has been shown during osteoblast-mediated mineralization (Woeckel et al., 2013a), while in human T47D breast cancer cells PPAR$\gamma$ binds VDR and represses its transcriptional activity, possibly also by competing for RXR heterodimerization (Alimirah et al., 2012). Titration out of common co-activators, but not of RXR, may be the mechanism by which ligand-bound VDR represses retinoic acid receptor (RAR) transactivation in GH4C1 pituitary cells (Jiménez-Lara and Aranda, 1999). The relation between $1 \alpha, 25(\mathrm{OH})_{2} \mathrm{D}_{3}$ and retinoic acid is however complex, as cooperative effects on target genes and cellular outcome (proliferation inhibition and differentiation) have been described in other systems (Tavera-Mendoza et al., 2006; Anand et al., 2008; $\mathrm{Ng}$ et al., 2010). As for estrogen receptor (ER), D. Feldman's group has shown that $1 \alpha, 25(\mathrm{OH})_{2} \mathrm{D}_{3}$ exerts a multilevel protective effect against breast cancer that includes the inhibition of estrogen synthesis through the direct and indirect repression of aromatase (CYP19) and the downregulation of ER- $\alpha$ expression through two VDREs in its promoter region (Krishnan et al., 2010; Swami et al., 2013). Likewise, there is a complex and unresolved relationship between $1 \alpha, 25(\mathrm{OH})_{2} \mathrm{D}_{3}$ and androgen receptor (AR) synthesis and signaling. $1 \alpha, 25(\mathrm{OH})_{2} \mathrm{D}_{3}$ induces $\mathrm{AR}$ in LNCaP cells (Zhao et al., 1999) while AR reduces VDR transcriptional activity (Ting et al., 2005), perhaps in some cells by a mechanism mediated by prohibitin (Mooso et al., 2010). In addition, $1 \alpha, 25(\mathrm{OH})_{2} \mathrm{D}_{3}$ inhibits glucuronidation and so, inactivation of androgen in prostate cancer cells through the repression of UDP-glucuronosyltransferases (UGT) 2B15 and 2B17, which is counterintuitive given the growth promoting action of androgen and the antiproliferative effect of $1 \alpha, 25(\mathrm{OH})_{2} \mathrm{D}_{3}$ in prostate cancer cells (Kaeding et al., 2008). In human bladder, $1 \alpha, 25(\mathrm{OH})_{2} \mathrm{D}_{3}$ and analogs inhibit cell proliferation promoted by androgen and keratinocyte growth factor and induce apoptosis at least in part by repressing Bcl-2 expression (Crescioli et al., 2005).

Pituitary transcription factor (Pit)-1 activates growth hormone and prolactin genes in the anterior pituitary and also in breast cancer cells (Seoane and Pérez-Fernández, 2006). In MCF7 cells, VDR homodimers bind the PIT-1 promoter and inhibit its expression in the presence of $1 \alpha, 25(\mathrm{OH})_{2} \mathrm{D}_{3}$ without involvement of RXR (Seoane and Pérez-Fernández, 2006).

\section{CONCLUSIONS}

The available evidence shows that the classical view of VDR only as a nuclear-acting ligand-modulated transcription factor that regulates the rate of transcription of those genes to which it binds is outdated. Instead, VDR and its ligand constitute a multilevel main regulator of gene expression in higher cells acting directly or indirectly, and via a variety of different mechanisms, on many signaling pathways. Some of them are triggered from the plasma membrane by paracrine or endocrine agents, and $1 \alpha, 25(\mathrm{OH})_{2} \mathrm{D}_{3}$ interacts at different levels: membrane receptors, cytosolic signaling molecules or effector nuclear transcription factors. In most cases $1 \alpha, 25(\mathrm{OH})_{2} \mathrm{D}_{3}$ action is mediated by nuclear VDR but in a few others this is unclear and non-canonical VDR-independent or extranuclear effects have been proposed. Available studies show that $1 \alpha, 25(\mathrm{OH})_{2} \mathrm{D}_{3}$ and these signaling pathways interact variably and with distinct outcomes in a cell/tissue-specific fashion and sometimes also differentially between normal and malignant cells.

\section{PERSPECTIVES}

The increasingly recognized importance of its non-cell autonomous actions has widened the scope of the study of $1 \alpha, 25(\mathrm{OH})_{2} \mathrm{D}_{3}$. On the one hand, an in-depth study of the interplay between $1 \alpha, 25(\mathrm{OH})_{2} \mathrm{D}_{3}$ and other agents, which seems to be cell-specific in terms of biological outcome, is necessary to elucidate the possibilities of combined therapies using vitamin D compounds and inhibitors or activators of a variety of signaling pathways. On the other hand, several of these interactions take place at the intercellular level. By using high-throughput techniques and genome-wide analyses, we expect to be able to identify secreted paracrine and intracellular mediators of the interaction between $1 \alpha, 25(\mathrm{OH})_{2} \mathrm{D}_{3}$ and other signaling pathways responsible for the regulatory actions of $1 \alpha, 25(\mathrm{OH})_{2} \mathrm{D}_{3}$ in the organism. Future research should aim to discern how vitamin D compounds modulate tissue and organ physiology and how they may be used to treat pathological processes such as infections, autoimmune disorders, or cancer.

\section{AUTHOR CONTRIBUTIONS}

María Jesús Larriba, José Manuel González-Sancho, Félix Bonilla, and Alberto Muñoz wrote the manuscript.

\section{ACKNOWLEDGMENTS}

We thank Robin Rycroft for his valuable assistance in the preparation of the English manuscript. The work in the authors' laboratory is supported by Ministerio de Economía y Competitividad of Spain (SAF2010-18302, BFU2010-19659), Fondo Europeo de Desarrollo Regional-Instituto de Salud 
Carlos III (RD12/0036/0021, RD12/0036/0041), and Comunidad de Madrid (S2010/BMD-2344, Colomics2).

\section{REFERENCES}

Adorini, L., and Penna, G. (2008). Control of autoimmune diseases by the vitamin D endocrine system. Nat. Clin. Pract. Rheumatol. 4, 404-412. doi: 10.1038/ncprheum 0855

Aguilera, O., Peña, C., García, J. M., Larriba, M. J., Ordóñez-Morán, P., Navarro, D., et al. (2007). The Wnt antagonist DICKKOPF-1 gene is induced by $1 \alpha, 25-$ dihydroxyvitamin $\mathrm{D}_{3}$ associated to the differentiation of human colon cancer cells. Carcinogenesis 28, 1877-1884. doi: 10.1093/carcin/bgm094

Alimirah, F., Peng, X., Yuan, L., Mehta, R. R., von Knethen, A., Choubey, D., et al. (2012). Crosstalk between the peroxisome proliferator-activated receptor $\gamma(\operatorname{PPAR} \gamma)$ and the vitamin $\mathrm{D}$ receptor (VDR) in human breast cancer cells: PPAR $\gamma$ binds to VDR and inhibits $1 \alpha, 25$-dihydroxyvitamin $\mathrm{D}_{3}$ mediated transactivation. Exp. Cell Res. 318, 2490-2497. doi: 10.1016/j.yexcr.2012. 07.020

Alroy, I., Towers, T. L., and Freedman, L. P. (1995). Transcriptional repression of the interleukin- 2 gene by vitamin $\mathrm{D}_{3}$ : direct inhibition of NFATp/AP- 1 complex formation by a nuclear hormone receptor. Mol. Cell. Biol. 15, 5789-5799.

Alvarez-Díaz, S., Larriba, M. J., López-Otín, C., and Muñoz, A. (2010). Vitamin D: proteases, protease inhibitors and cancer. Cell Cycle 9, 32-37. doi: 10.4161/cc.9.1.10266

Alvarez-Díaz, S., Valle, N., Ferrer-Mayorga, G., Lombardía, L., Herrera, M., Domínguez, O., et al. (2012). MicroRNA-22 is induced by vitamin D and contributes to its antiproliferative, antimigratory and gene regulatory effects in colon cancer cells. Hum. Mol. Genet. 21, 2157-2165. doi: 10.1093/hmg/dds031

An, B. S., Tavera-Mendoza, L. E., Dimitrov, V., Wang, X., Calderon, M. R., Wang, H. J., et al. (2010). Stimulation of Sirt1-regulated FoxO protein function by the ligand-bound vitamin D receptor. Mol. Cell. Biol. 30, 4890-4900. doi: 10.1128/MCB.00180-10

Anand, P. K., Kaul, D., and Sharma, M. (2008). Synergistic action of vitamin D and retinoic acid restricts invasion of macrophages by pathogenic mycobacteria. J. Microbiol. Immunol. Infect. 41, 17-25.

Andl, C. D., and Rustgi, A. K. (2005). No one-way street: cross-talk between Ecadherin and receptor tyrosine kinase (RTK) signaling: a mechanism to regulate RTK activity. Cancer Biol. Ther. 4, 28-31. doi: 10.4161/cbt.4.1.1431

Barbáchano, A., Ordóñez-Morán, P., García, J. M., Sánchez, A., Pereira, F., Larriba, M. J., et al. (2010). SPROUTY-2 and E-cadherin regulate reciprocally and dictate colon cancer cell tumourigenicity. Oncogene 29, 4800-4813. doi: 10.1038/onc.2010.225

Ben-Shoshan, M., Amir, S., Dang, D. T., Dang, L. H., Weisman, Y., and Mabjeesh, N. J. (2007). 1 $\alpha$,25-dihydroxyvitamin $\mathrm{D}_{3}$ (Calcitriol) inhibits hypoxia-inducible factor-1/vascular endothelial growth factor pathway in human cancer cells. Mol. Cancer Ther. 6, 1433-1439. doi: 10.1158/1535-7163.MCT-06-0677

Bijlsma, M. F., Spek, C. A., Zivkovic, D., van de Water, S., Rezaee, F., and Peppelenbosch, M. P. (2006). Repression of smoothened by patcheddependent (pro-)vitamin $\mathrm{D}_{3}$ secretion. PLoS Biol. 4:e232. doi: 10.1371/journal.pbio.0040232

Bikle, D. D. (2011). The vitamin D receptor: a tumor suppressor in skin. Discov. Med. 11, 7-17.

Bikle, D. D., Elalieh, H., Welsh, J., Oh, D., Cleaver, J., and Teichert, A. (2013). Protective role of vitamin D signaling in skin cancer formation. J. Steroid Biochem. Mol. Biol. 136, 271-279. doi: 10.1016/j.jsbmb.2012.09.021

Brosseau, C., Pirianov, G., and Colston, K. W. (2013). Role of insulin-like growth factor binding protein-3 in 1,25-dihydroxyvitamin- $\mathrm{D}_{3}$-induced breast cancer cell apoptosis. Int. J. Cell Biol. 2013, 960378. doi: 10.1155/2013/960378

Brüggemann, L. W., Queiroz, K. C., Zamani, K., van Straaten, A., Spek, C. A., and Bijlsma, M. F. (2010). Assessing the efficacy of the hedgehog pathway inhibitor vitamin $\mathrm{D}_{3}$ in a murine xenograft model for pancreatic cancer. Cancer Biol. Ther. 10, 79-88. doi: 10.4161/cbt.10.1.12165

Bruns, D. E., Krishnan, A. V., Feldman, D., Gray, R. W., Christakos, S., Hirsch, G. N., et al. (1989). Epidermal growth factor increases intestinal calbindin-D9k and 1,25-dihydroxyvitamin D receptors in neonatal rats. Endocrinology 125, 478-485. doi: 10.1210/endo-125-1-478

Cabrita, M. A., and Christofori, G. (2008). Sprouty proteins, masterminds of receptor tyrosine kinase signaling. Angiogenesis 11, 53-62. doi: 10.1007/s10456008-9089-1
Cardus, A., Panizo, S., Encinas, M., Dolcet, X., Gallego, C., Aldea, M., et al. (2009). 1,25-dihydroxyvitamin $\mathrm{D}_{3}$ regulates VEGF production through a vitamin D response element in the VEGF promoter. Atherosclerosis 204, 85-89. doi: 10.1016/j.atherosclerosis.2008.08.020

Carlberg, C., and Campbell, M. J. (2013). Vitamin D receptor signaling mechanisms: integrated actions of a well-defined transcription factor. Steroids 78, 127-136. doi: 10.1016/j.steroids.2012.10.019

Chattopadhyay, N., MacLeod, R. J., Tfelt-Hansen, J., and Brown, E. M. (2003). $1 \alpha, 25(\mathrm{OH})_{2}$-vitamin $\mathrm{D}_{3}$ inhibits HGF synthesis and secretion from MG-63 human osteosarcoma cells. Am. J. Physiol. Endocrinol. Metab. 284, E219-E227. doi: 10.1152/ajpendo.00247.2002

Chen, A., Davis, B. H., Bissonnette, M., Scaglione-Sewell, B., and Brasitus, T. A. (1999). 1,25-Dihydroxyvitamin $\mathrm{D}_{3}$ stimulates activator protein-1dependent Caco-2 cell differentiation. J. Biol. Chem. 274, 35505-35513. doi: $10.1074 /$ jbc.274.50.35505

Chen, A., Davis, B. H., Sitrin, M. D., Brasitus, T. A., and Bissonnette, M. (2002). Transforming growth factor- $\beta 1$ signaling contributes to Caco-2 cell growth inhibition induced by $1,25(\mathrm{OH})_{2} \mathrm{D}_{3}$. Am. J. Physiol. Gastrointest. Liver Physiol. 283, G864-G874. doi: 10.1152/ajpgi.00524.2001

Chen, H., Reed, G., Guardia, J., Lakhan, S., Couture, O., Hays, E., et al. (2013). Vitamin D directly regulates Mdm2 gene expression in osteoblasts. Biochem. Biophys. Res. Commun. 430, 370-374. doi: 10.1016/j.bbrc.2012.11.003

Chen, K., Aenlle, K. K., Curtis, K. M., Roos, B. A., and Howard, G. A. (2012). Hepatocyte growth factor (HGF) and 1,25-dihydroxyvitamin D together stimulate human bone marrow-derived stem cells toward the osteogenic phenotype by HGF-induced up-regulation of VDR. Bone 51, 69-77. doi: 10.1016/j.bone.2012.04.002

Chen, K., Perez-Stable, C., D'Ippolito, G., Schiller, P. C., Roos, B. A., and Howard, G. A. (2011). Human bone marrow-derived stem cell proliferation is inhibited by hepatocyte growth factor via increasing the cell cycle inhibitors p53, p21 and p27. Bone 49, 1194-1204. doi: 10.1016/j.bone.2011.08.023

Clevers, H., and Nusse, R. (2012). Wnt/B-catenin signaling and disease. Cell 149, 1192-1205. doi: 10.1016/j.cell.2012.05.012

Crescioli, C., Morelli, A., Adorini, L., Ferruzzi, P., Luconi, M., Vannelli, G. B., et al. (2005). Human bladder as a novel target for vitamin D receptor ligands. J. Clin. Endocrinol. Metab. 90, 962-972. doi: 10.1210/jc.2004-1496

Cui, J., Ma, C., Qiu, J., Ma, X., Wang, X., Chen, H., et al. (2011). A novel interaction between insulin-like growth factor binding protein- 6 and the vitamin $\mathrm{D}$ receptor inhibits the role of vitamin $\mathrm{D}_{3}$ in osteoblast differentiation. Mol. Cell. Endocrinol. 338, 84-92. doi: 10.1016/j.mce.2011.03.011

Desprez, P. Y., Poujol, D., Falette, N., Lefebvre, M. F., and Saez, S. (1991). 1,25Dihydroxyvitamin $\mathrm{D}_{3}$ increases epidermal growth factor receptor gene expression in BT-20 breast carcinoma cells. Biochem. Biophys. Res. Commun. 176, 1-6. doi: 10.1016/0006-291X(91)90880-G

Ding, N., Yu, R. T., Subramaniam, N., Sherman, M. H., Wilson, C., Rao, R., et al. (2013). A vitamin D receptor/SMAD genomic circuit gates hepatic fibrotic response. Cell 153, 601-613. doi: 10.1016/j.cell.2013.03.028

D'Ippolito, G., Schiller, P. C., Perez-stable, C., Balkan, W., Roos, B. A., and Howard, G. A. (2002). Cooperative actions of hepatocyte growth factor and 1,25dihydroxyvitamin $\mathrm{D}_{3}$ in osteoblastic differentiation of human vertebral bone marrow stromal cells. Bone 31, 269-275. doi: 10.1016/S8756-3282(02)00820-7

Dunlop, T. W., Vaisanen, S., Frank, C., Molnar, F., Sinkkonen, L., and Carlberg, C. (2005). The human peroxisome proliferator-activated receptor $\delta$ gene is a primary target of $1 \alpha, 25$-dihydroxyvitamin $\mathrm{D}_{3}$ and its nuclear receptor. J. Mol. Biol. 349, 248-260. doi: 10.1016/j.jmb.2005.03.060

Fabri, M., Stenger, S., Shin, D. M., Yuk, J. M., Liu, P. T., Realegeno, S., et al. (2011). Vitamin D is required for IFN- $\gamma$-mediated antimicrobial activity of human macrophages. Sci. Transl. Med. 3, 104ra102. doi: 10.1126/scitranslmed.30 03045

Garcia, L. A., Ferrini, M. G., Norris, K. C., and Artaza, J. N. (2013). $1,25(\mathrm{OH})_{2}$ vitamin $\mathrm{D}_{3}$ enhances myogenic differentiation by modulating the expression of key angiogenic growth factors and angiogenic inhibitors in $\mathrm{C}_{2} \mathrm{C}_{12}$ skeletal muscle cells. J. Steroid Biochem. Mol. Biol. 133, 1-11. doi: 10.1016/j.jsbmb.2012.09.004

Garcia, L. A., King, K. K., Ferrini, M. G., Norris, K. C., and Artaza, J. N. (2011). $1,25(\mathrm{OH})_{2}$ vitamin $\mathrm{D}_{3}$ stimulates myogenic differentiation by inhibiting cell proliferation and modulating the expression of promyogenic growth factors and myostatin in C2C12 skeletal muscle cells. Endocrinology 152, 2976-2986. doi: 10.1210/en.2011-0159 
Geldmeyer-Hilt, K., Heine, G., Hartmann, B., Baumgrass, R., Radbruch, A., and Worm, M. (2011). 1,25-dihydroxyvitamin $\mathrm{D}_{3}$ impairs NF-кB activation in human naïve B cells. Biochem. Biophys. Res. Commun. 407, 699-702. doi: 10.1016/j.bbrc.2011.03.078

Goupil, D., Ethier, C., Zarnegar, R., and Gascon-Barre, M. (1997). Hepatic expression of regeneration marker genes following partial hepatectomy in the rat. Influence of 1,25-dihydroxyvitamin $\mathrm{D}_{3}$ in hypocalcemia. J. Hepatol. 26, 659-668.

Gruber, H. E., Hoelscher, G., Ingram, J. A., Chow, Y., Loeffler, B., and Hanley, E. N. Jr. (2008). 1,25(OH) $)_{2}$-vitamin $\mathrm{D}_{3}$ inhibits proliferation and decreases production of monocyte chemoattractant protein-1, thrombopoietin, VEGF, and angiogenin by human annulus cells in vitro. Spine 33, 755-765. doi: 10.1097/BRS.0b013e3181695d59

Grumbles, R. M., Howell, D. S., Wenger, L., Altman, R. D., Howard, G. A., and Roos, B. A. (1996). Hepatocyte growth factor and its actions in growth plate chondrocytes. Bone 19, 255-261. doi: 10.1016/8756-3282(96)00180-9

Grundmann, M., Haidar, M., Placzko, S., Niendorf, R., Darashchonak, N., Hubel, C. A., et al. (2012). Vitamin D improves the angiogenic properties of endothelial progenitor cells. Am. J. Physiol. Cell Physiol. 303, C954-C962. doi: 10.1152/ajpcell.00030.2012

Guan, H., Liu, C., Chen, Z., Wang, L., Li, C., Zhao, J., et al. (2013). 1,25Dihydroxyvitamin $\mathrm{D}_{3}$ up-regulates expression of hsa-let-7a-2 through the interaction of VDR/VDRE in human lung cancer A549 cells. Gene 522, 142-146. doi: 10.1016/j.gene.2013.03.065

Gynther, P., Toropainen, S., Matilainen, J. M., Seuter, S., Carlberg, C., and Väisänen, S. (2011). Mechanism of $1 \alpha, 25$-dihydroxyvitamin $\mathrm{D}_{3}$-dependent repression of interleukin-12B. Biochim. Biophys. Acta 1813, 810-818. doi: 10.1016/j.bbamcr.2011.01.037

Harant, H., Wolff, B., and Lindley, I. J. (1998). 1 $\alpha, 25$-Dihydroxyvitamin $\mathrm{D}_{3}$ decreases DNA binding of nuclear factor- $\kappa \mathrm{B}$ in human fibroblasts. FEBS Lett. 436, 329-334. doi: 10.1016/S0014-5793(98)01153-3

Huang, Y.-C., Chen, J.-Y., and Hung, W.-C. (2004). Vitamin $D_{3}$ receptor/Sp1 complex is required for the induction of $\mathrm{p} 27^{\mathrm{KIP} 1}$ expression by vitamin $\mathrm{D}_{3}$. Oncogene 23, 4856-4861. doi: 10.1038/sj.onc. 1207621

Huang, Y.-C., and Hung, W.-C. (2006). 1,25-Dihydroxyvitamin $\mathrm{D}_{3}$ transcriptionally represses $\mathrm{p} 45^{\mathrm{Skp} 2}$ expression via the $\mathrm{Sp} 1$ sites in human prostate cancer cells. J. Cell. Physiol. 209, 363-369. doi: 10.1002/jcp.20741

Inaba, M., Koyama, H., Hino, M., Okuno, S., Terada, M., Nishizawa, Y., et al. (1993). Regulation of release of hepatocyte growth factor from human promyelocytic leukemia cells, HL-60, by 1,25-dihydroxyvitamin $\mathrm{D}_{3}, 12-\mathrm{O}$ tetradecanoylphorbol 13-acetate, and dibutyryl cyclic adenosine monophosphate. Blood 82, 53-59.

Inoue, T., Kamiyama, J., and Sakai, T. (1999). Sp1 and NF-Y synergistically mediate the effect of vitamin $\mathrm{D}_{3}$ in the $\mathrm{p} 27^{\mathrm{KIP} 1}$ gene promoter that lacks vitamin D response elements. J. Biol. Chem. 274, 32309-32317. doi: 10.1074/jbc.274.45.32309

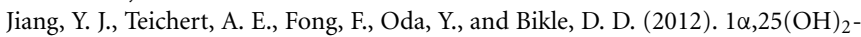
Dihydroxyvitamin $\mathrm{D}_{3} /$ VDR protects the skin from UVB-induced tumor formation by interacting with the $\beta$-catenin pathway. J. Steroid Biochem. Mol. Biol. 136, 229-232. doi: 10.1016/j.jsbmb.2012.09.024

Jiménez-Lara, A. M., and Aranda, A. (1999). Vitamin D represses retinoic aciddependent transactivation of the retinoic acid receptor- $\beta 2$ promoter: the AF- 2 domain of the vitamin D receptor is required for transrepression. Endocrinology 140, 2898-2907. doi: 10.1210/endo.140.6.6770

Kaeding, J., Belanger, J., Caron, P., Verreault, M., Belanger, A., and Barbier, O. (2008). Calcitrol $\left(1 \alpha, 25\right.$-dihydroxyvitamin $\left.\mathrm{D}_{3}\right)$ inhibits androgen glucuronidation in prostate cancer cells. Mol. Cancer Ther. 7, 380-390. doi: 10.1158/15357163.MCT-07-0455

Kaler, P., Augenlicht, L., and Klampfer, L. (2009). Macrophage-derived IL-1 $\beta$ stimulates Wnt signaling and growth of colon cancer cells: a crosstalk interrupted by vitamin $\mathrm{D}_{3}$. Oncogene 28, 3892-3902. doi: 10.1038/onc.2009.247

Kasiappan, R., Shen, Z., Tse, A. K., Jinwal, U., Tang, J., Lungchukiet, P., et al. (2012). 1,25-Dihydroxyvitamin $\mathrm{D}_{3}$ suppresses telomerase expression and human cancer growth through microRNA-498. J. Biol. Chem. 287, 41297-41309. doi: 10.1074/jbc.M112.407189

Kostaras, E., Sflomos, G., Pedersen, N. M., Stenmark, H., Fotsis, T., and Murphy, C. (2013). SARA and RNF11 interact with each other and ESCRT-0 core proteins and regulate degradative EGFR trafficking. Oncogene 32, 5220-5232. doi: 10.1038/onc.2012.554
Kovalenko, P. L., Zhang, Z., Cui, M., Clinton, S. K., and Fleet, J. C. (2010). 1,25 dihydroxyvitamin D-mediated orchestration of anticancer, transcript-level effects in the immortalized, non-transformed prostate epithelial cell line, RWPE1. BMC Genomics 11:26. doi: 10.1186/1471-2164-11-26

Krishnan, A. V., and Feldman, D. (2010). Molecular pathways mediating the antiinflammatory effects of calcitriol: implications for prostate cancer chemoprevention and treatment. Endocr. Relat. Cancer 17, R19-R38. doi: 10.1677/ERC09-0139

Krishnan, A. V., Swami, S., Peng, L., Wang, J., Moreno, J., and Feldman, D. (2010). Tissue-selective regulation of aromatase expression by calcitriol: implications for breast cancer therapy. Endocrinology 151, 32-42. doi: 10.1210/en.2009-0855

Larriba, M. J., González-Sancho, J. M., Barbáchano, A., Niell, N., Ferrer-Mayorga, G., and Muñoz, A. (2013). Vitamin D is a multilevel repressor of Wnt/ $\beta$-catenin signaling in cancer cells. Cancers 5, 1242-1260. doi: 10.3390/cancers5041242

Li, J., Jin, D., Fu, S., Mei, G., Zhou, J., Lei, L., et al. (2013). Insulin-like growth factor binding protein-3 modulates osteoblast differentiation via interaction with vitamin D receptor. Biochem. Biophys. Res. Commun. 436, 632-637. doi: 10.1016/j.bbrc.2013.04.111

Li, P., Li, C., Zhao, X., Zhang, X., Nicosia, S. V., and Bai, W. (2004). p27 ${ }^{\text {Kip1 }}$ stabilization and $G_{1}$ arrest by 1,25-dihydroxyvitamin $D_{3}$ in ovarian cancer cells mediated through down-regulation of cyclin E/cyclin-dependent kinase 2 and Skp1-Cullin-F-box protein/Skp2 ubiquitin ligase. J. Biol. Chem. 279, 25260-25267. doi: 10.1074/jbc.M311052200

Li, Y., Spataro, B. C., Yang, J., Dai, C., and Liu, Y. (2005). 1,25-dihydroxyvitamin $\mathrm{D}$ inhibits renal interstitial myofibroblast activation by inducing hepatocyte growth factor expression. Kidney Int. 68, 1500-1510. doi: 10.1111/j.15231755.2005.00562.x

Lin, R., Wang, T. T., Miller, W. H., and White, J. H. (2003). Inhibition of F-Box protein $\mathrm{p} 45^{\mathrm{SKP} 2}$ expression and stabilization of cyclin-dependent kinase inhibitor p27 ${ }^{\mathrm{KIP} 1}$ in vitamin D analog-treated cancer cells. Endocrinology 144, 749-753. doi: 10.1210/en.2002-0026

Liu, P. T., Schenk, M., Walker, V. P., Dempsey, P. W., Kanchanapoomi, M., Wheelwright, M., et al. (2009). Convergence of IL-1 $\beta$ and VDR activation pathways in human TLR2/1-induced antimicrobial responses. PLOS ONE 4:e5810. doi: 10.1371/journal.pone.0005810

Liu, P. T., Stenger, S., Li, H., Wenzel, L., Tan, B. H., Krutzik, S. R., et al. (2006). Tolllike receptor triggering of a vitamin $\mathrm{D}$-mediated human antimicrobial response. Science 311, 1770-1773. doi: 10.1126/science.1123933

Luderer, H. F., Gori, F., and Demay, M. B. (2011). Lymphoid enhancer-binding factor-1 (LEF1) interacts with the DNA-binding domain of the vitamin D receptor. J. Biol. Chem. 286, 18444-18451. doi: 10.1074/jbc.M110.188219

Malinen, M., Ryynänen, J., Heinäniemi, M., Väisänen, S., and Carlberg, C. (2011). Cyclical regulation of the insulin-like growth factor binding protein 3 gene in response to 1 $\alpha, 25$-dihydroxyvitamin $\mathrm{D}_{3}$. Nucleic Acids Res. 39, 502-512. doi: $10.1093 / \mathrm{nar} / \mathrm{gkq} 820$

Matilainen, J. M., Husso, T., Toropainen, S., Seuter, S., Turunen, M. P., Gynther, P., et al. (2010a). Primary effect of $1 \alpha, 25(\mathrm{OH})_{2} \mathrm{D}_{3}$ on IL-10 expression in monocytes is short-term down-regulation. Biochim. Biophys. Acta 1803, 1276-1286. doi: 10.1016/j.bbamcr.2010.07.009

Matilainen, J. M., Räsänen, A., Gynther, P., and Väisänen, S. (2010b). The genes encoding cytokines IL-2, IL-10 and IL-12B are primary $1 \alpha, 25(\mathrm{OH})_{2} \mathrm{D}_{3}$ target genes. J. Steroid Biochem. Mol. Biol. 121, 142-145. doi: 10.1016/j.jsbmb.2010.03.020

Matilainen, M., Malinen, M., Saavalainen, K., and Carlberg, C. (2005). Regulation of multiple insulin-like growth factor binding protein genes by $1 \alpha, 25$ dihydroxyvitamin $\mathrm{D}_{3}$. Nucleic Acids Res. 33, 5521-5532. doi: 10.1093/nar/ gki872

Maund, S. L., Barclay, W. W., Hover, L. D., Axanova, L. S., Sui, G., Hipp, J. D., et al. (2011). Interleukin- $1 \alpha$ mediates the antiproliferative effects of 1,25-dihydroxyvitamin $\mathrm{D}_{3}$ in prostate progenitor/stem cells. Cancer Res. 71, 5276-5286. doi: 10.1158/0008-5472.CAN-10-2160

Mooso, B., Madhav, A., Johnson, S., Roy, M., Moore, M. E., Moy, C., et al. (2010). Androgen Receptor regulation of Vitamin D Receptor in response of castrationresistant prostate cancer cells to $1 \alpha$-Hydroxyvitamin $\mathrm{D}_{5}$ - a calcitriol analog. Genes Cancer 1, 927-940. doi: 10.1177/1947601910385450

Muthian, G., Raikwar, H. P., Rajasingh, J., and Bright, J. J. (2006). 1,25 Dihydroxyvitamin- $\mathrm{D}_{3}$ modulates JAK-STAT pathway in IL-12/IFN $\gamma$ axis leading to Th1 response in experimental allergic encephalomyelitis. J. Neurosci. Res. 83, 1299-1309. doi: 10.1002/jnr.20826 
Mutt, S. J., Karhu, T., Lehtonen, S., Lehenkari, P., Carlberg, C., Saarnio, J., et al. (2012). Inhibition of cytokine secretion from adipocytes by 1,25dihydroxyvitamin $\mathrm{D}_{3}$ via the NF-кB pathway. FASEB J. 26, 4400-4407. doi: 10.1096/fj.12-210880

Ng, K. Y., Ma, M. T., Leung, K. K., and Leung, P. S. (2010). Vitamin D and vitamin A receptor expression and the proliferative effects of ligand activation of these receptors on the development of pancreatic progenitor cells derived from human fetal pancreas. Stem Cell Rev. 7, 53-63. doi: 10.1007/s12015-010-9146-1

Oh, Y. S., Kim, E. J., Schaffer, B. S., Kang, Y. H., Binderup, L., MacDonald, R. G., et al. (2001). Synthetic low-calcaemic vitamin $\mathrm{D}_{3}$ analogues inhibit secretion of insulin-like growth factor II and stimulate production of insulin-like growth factor-binding protein-6 in conjunction with growth suppression of HT-29 colon cancer cells. Mol. Cell. Endocrinol. 183, 141-149. doi: 10.1016/S03037207(01)00598-6

Okuda, N., Takeda, S., Shinomiya, K., Muneta, T., Itoh, S., Noda, M., et al. (2007). ED-71, a novel vitamin D analog, promotes bone formation and angiogenesis and inhibits bone resorption after bone marrow ablation. Bone 40, 281-292. doi: 10.1016/j.bone.2006.08.017

Pálmer, H. G., González-Sancho, J. M., Espada, J., Berciano, M. T., Puig, I., Baulida, J., et al. (2001). Vitamin $\mathrm{D}_{3}$ promotes the differentiation of colon carcinoma cells by the induction of E-cadherin and the inhibition of $\beta$-catenin signaling. J. Cell Biol. 154, 369-387. doi: 10.1083/jcb.200102028

Pálmer, H. G., Sánchez-Carbayo, M., Ordóñez-Morán, P., Larriba, M. J., CordónCardó, C., and Muñoz, A. (2003). Genetic signatures of differentiation induced by $1 \alpha, 25$-dihydroxyvitamin $\mathrm{D}_{3}$ in human colon cancer cells. Cancer Res. 63, 7799-7806.

Pan, Q., and Simpson, R. U. (1999). c-Myc intron element-binding proteins are required for 1,25-dihydroxyvitamin $\mathrm{D}_{3}$ regulation of c-myc during HL-60 cell differentiation and the involvement of HOXB4. J. Biol. Chem. 274, 8437-8444. doi: $10.1074 /$ jbc.274.13.8437

Parikh, G., Varadinova, M., Suwandhi, P., Araki, T., Rosenwaks, Z., Poretsky, L., et al. (2010). Vitamin D regulates steroidogenesis and insulin-like growth factor binding protein-1 (IGFBP-1) production in human ovarian cells. Horm. Metab. Res. 42, 754-757. doi: 10.1055/s-0030-1262837

Pickup, M., Novitskiy, S., and Moses, H. L. (2013). The roles of TGF $\beta$ in the tumour microenvironment. Nat. Rev. Cancer 13, 788-799. doi: 10.1038/nrc3500

Qadan, L. R., Perez-Stable, C. M., Schwall, R. H., Burnstein, K. L., Ostenson, R. C., Howard, G. A., et al. (2000). Hepatocyte growth factor and vitamin D cooperatively inhibit androgen-unresponsive prostate cancer cell lines. Endocrinology 141, 2567-2573. doi: 10.1210/endo.141.7.7546

Reichrath, S., and Reichrath, J. (2012). No evidence for induction of key components of the Notch signaling pathway (Notch-1, Jagged-1) by treatment with UV-B, $1,25(\mathrm{OH})_{2} \mathrm{D}_{3}$, and/or epigenetic drugs (TSA, 5-Aza) in human keratinocytes in vitro. Dermatoendocrinology 4, 44-52. doi: 10.4161/derm. 19027

Ren, Z., Li, W., Zhao, Q., Ma, L., and Zhu, J. (2012). The impact of 1,25dihydroxyvitamin $\mathrm{D}_{3}$ on the expressions of vascular endothelial growth factor and transforming growth factor- $\beta_{1}$ in the retinas of rats with diabetes. Diabetes Res. Clin. Pract. 98, 474-480. doi: 10.1016/j.diabres.2012.09.028

Rodilla, V., Villanueva, A., Obrador-Hevia, A., Robert-Moreno, A., FernandezMajada, V., Grilli, A., et al. (2009). Jagged1 is the pathological link between Wnt and Notch pathways in colorectal cancer. Proc. Natl. Acad. Sci. U.S.A. 106, 6315-6320. doi: 10.1073/pnas.0813221106

Ryynänen, J., and Carlberg, C. (2013). Primary 1,25-dihydroxyvitamin $\mathrm{D}_{3}$ response of the interleukin 8 gene cluster in human monocyte- and macrophage-like cells. PLoS ONE 8:e78170. doi: 10.1371/journal.pone.0078170

Salehi-Tabar, R., Nguyen-Yamamoto, L., Tavera-Mendoza, L. E., Quail, T., Dimitrov, V., An, B. S., et al. (2012). Vitamin D receptor as a master regulator of the c-MYC/MXD1 network. Proc. Natl. Acad. Sci. U.S.A. 109, 18827-18832. doi: $10.1073 /$ pnas. 1210037109

Schauber, J., Dorschner, R. A., Coda, A. B., Buchau, A. S., Liu, P. T., Kiken, D., et al. (2007). Injury enhances TLR2 function and antimicrobial peptide expression through a vitamin D-dependent mechanism. J. Clin. Invest. 117, 803-811. doi: 10.1172/JCI30142

Schlaeppi, J. M., Gutzwiller, S., Finkenzeller, G., and Fournier, B. (1997). 1,25Dihydroxyvitamin $\mathrm{D}_{3}$ induces the expression of vascular endothelial growth factor in osteoblastic cells. Endocr. Res. 23, 213-229.

Schnabel, M., Fichtel, I., Gotzen, L., and Schlegel, J. (2002). Differential expression of Notch genes in human osteoblastic cells. Int. J. Mol. Med. 9, 229-232.
Seoane, S., and Pérez-Fernández, R. (2006). The vitamin D receptor represses transcription of the pituitary transcription factor Pit-1 gene without involvement of the retinoid X receptor. Mol. Endocrinol. 20, 735-748. doi: 10.1210/me.20050253

Sertznig, P., Dunlop, T., Seifert, M., Tilgen, W., and Reichrath, J. (2009a). Cross-talk between vitamin D receptor (VDR)- and peroxisome proliferatoractivated receptor (PPAR)-signaling in melanoma cells. Anticancer Res. 29, $3647-3658$.

Sertznig, P., Seifert, M., Tilgen, W., and Reichrath, J. (2009b). Activation of vitamin $\mathrm{D}$ receptor (VDR)- and peroxisome proliferator-activated receptor (PPAR)-signaling pathways through $1,25(\mathrm{OH})_{2} \mathrm{D}_{3}$ in melanoma cell lines and other skin-derived cell lines. Dermatoendocrinology 1, 232-238. doi: 10.4161/derm.1.4.9629

Shah, S., Islam, M. N., Dakshanamurthy, S., Rizvi, I., Rao, M., Herrell, R., et al. (2006). The molecular basis of vitamin $\mathrm{D}$ receptor and $\beta$-catenin crossregulation. Mol. Cell 21, 799-809. doi: 10.1016/j.molcel.2006.01.037

Shalhoub, V., Shatzen, E. M., Ward, S. C., Young, J. I., Boedigheimer, M., Twehues, L., et al. (2010). Chondro/osteoblastic and cardiovascular gene modulation in human artery smooth muscle cells that calcify in the presence of phosphate and calcitriol or paricalcitol. J. Cell. Biochem. 111, 911-921. doi: 10.1002/jcb.22779

Shen, Q., and Christakos, S. (2005). The vitamin D receptor, Runx2, and the Notch signaling pathway cooperate in the transcriptional regulation of osteopontin. J. Biol. Chem. 280, 40589-40598. doi: 10.1074/jbc.M504166200

Shen, X., Mula, R. V. R., Li, J., Weigel, N. L., and Falzon, M. (2007). PTHrP contributes to the anti-proliferative and integrin $\alpha 6 \beta 4$-regulating effects of 1,25 dihydroxyvitamin $\mathrm{D}_{3}$. Steroids 72, 930-938. doi: 10.1016/j.steroids.2007.08.003

Staal, A., Birkenhäger, J. C., Pols, H. A. P., Buurman, C. J., Vink-van Wijngaarden, T., Kleinekoort, W. M., et al. (1994). Transforming growth factor $\beta$-induced dissociation between vitamin $\mathrm{D}$ receptor level and 1,25-dihydroxyvitamin $\mathrm{D}_{3}$ action in osteoblast-like cells. Bone Miner. 26, 27-42. doi: 10.1016/S01696009(08)80160-2

Staal, A., Geertsma-Kleinekoort, W. M. C., Van Den Bemd, G. J. C. M., Buurman, C. J., Birkenhäger, J. C., Pols, H. A. P., et al. (1998). Regulation of osteocalcin production and bone resorption by 1,25 -dihydroxyvitamin $\mathrm{D}_{3}$ in mouse long bones: interaction with the bone-derived growth factors TGF- $\beta$ and IGF-I. J. Bone Miner. Res. 13, 36-43. doi: 10.1359/jbmr.1998.13.1.36

Staal, A., Van Wijnen, A. J., Desai, R. K., Pols, H. A. P., Birkenhäger, J. C., Deluca, H. F., et al. (1996). Antagonistic effects of transforming growth factor- $\beta$ on vitamin $D_{3}$ enhancement of osteocalcin and osteopontin transcription: reduced interactions of vitamin $\mathrm{D}$ receptor/retinoid $\mathrm{X}$ receptor complexes with vitamin E response elements. Endocrinology 137, 2001-2011. doi: 10.1210/endo.137.5.8612541

Stambolsky, P., Tabach, Y., Fontemaggi, G., Weisz, L., Maor-Aloni, R., Siegfried, Z., et al. (2010). Modulation of the vitamin $\mathrm{D}_{3}$ response by cancer-associated mutant p53. Cancer Cell 17, 273-285. doi: 10.1016/j.ccr.2009.11.025

Sun, J., Kong, J., Duan, Y., Szeto, F. L., Liao, A., Madara, J. L., et al. (2006). Increased NF- $\mathrm{KB}$ activity in fibroblasts lacking the vitamin D receptor. Am. J. Physiol. Endocrinol. Metab. 291, E315-E322. doi: 10.1152/ajpendo.00590.2005

Swami, S., Krishnan, A. V., Peng, L., Lundqvist, J., and Feldman, D. (2013). Transrepression of the estrogen receptor promoter by calcitriol in human breast cancer cells via two negative vitamin D response elements. Endocr. Relat. Cancer 20, 565-577. doi: 10.1530/ERC-12-0281

Tang, J. Y., Xiao, T. Z., Oda, Y., Chang, K. S., Shpall, E., Wu, A., et al. (2011). Vitamin $\mathrm{D}_{3}$ inhibits hedgehog signaling and proliferation in murine basal cell carcinomas. Cancer Prev. Res. 4, 744-751. doi: 10.1158/1940-6207.CAPR-10-0285

Tang, W. B., Ling, G. H., Sun, L., and Liu, F. Y. (2010). Smad anchor for receptor activation (SARA) in TGF- $\beta$ signaling. Front. Biosci. 2, 857-860. doi: $10.2741 / \mathrm{E} 147$

Tavera-Mendoza, L., Wang, T. T., Lallemant, B., Zhang, R., Nagai, Y., Bourdeau, $\mathrm{V}$., et al. (2006). Convergence of vitamin $\mathrm{D}$ and retinoic acid signalling at a common hormone response element. EMBO Rep. 7, 180-185. doi: 10.1038/sj.embor.7400594

Thorne, J. L., Maguire, O., Doig, C. L., Battaglia, S., Fehr, L., Sucheston, L. E., et al. (2011). Epigenetic control of a VDR-governed feed-forward loop that regulates p21 $1^{\text {waf1/cip1 }}$ expression and function in non-malignant prostate cells. Nucleic Acids Res. 39, 2045-2056. doi: 10.1093/nar/gkq875

Ting, H. J., Bao, B. Y., Hsu, C. L., and Lee, Y. F. (2005). Androgen-receptor coregulators mediate the suppressive effect of androgen signals on vitamin $\mathrm{D}$ receptor activity. Endocrine 26, 1-9. doi: 10.1385/ENDO:26:1:001 
Tong, W.-M., Hofer, H., Ellinger, A., Peterlik, M., and Cross, H. S. (1999). Mechanism of antimitogenic action of vitamin D in human colon carcinoma cells: relevance for suppression of epidermal growth factor-stimulated cell growth. Oncol. Res. 11, 77-84.

Tong, W.-M., Kállay, E., Hofer, H., Hulla, W., Manhardt, T., Peterlik, M., et al. (1998). Growth regulation of human colon cancer cells by epidermal growth factor and 1,25-dihydroxyvitamin $\mathrm{D}_{3}$ is mediated by mutual modulation of receptor expression. Eur. J. Cancer 34, 2119-2125. doi: 10.1016/S09598049(98)00267-6

Toropainen, S., Väisänen, S., Heikkinen, S., and Carlberg, C. (2010). The down-regulation of the human MYC gene by the nuclear hormone $1 \alpha, 25$-dihydroxyvitamin $\mathrm{D}_{3}$ is associated with cycling of corepressors and histone deacetylases. J. Mol. Biol. 400, 284-294. doi: 10.1016/j.jmb. 2010.05.031

Towers, T. L., Staeva, T. P., and Freedman, L. P. (1999). A two-hit mechanism for vitamin D3-mediated transcriptional repression of the granulocytemacrophage colony-stimulating factor gene: vitamin D receptor competes for DNA binding with NFAT1 and stabilizes c-Jun. Mol. Cell. Biol. 19, 4191-4199.

Uhmann, A., Niemann, H., Lammering, B., Henkel, C., Hess, I., Nitzki, F., et al. (2011). Antitumoral effects of calcitriol in basal cell carcinomas involve inhibition of hedgehog signaling and induction of vitamin D receptor signaling and differentiation. Mol. Cancer Ther. 10, 2179-2188. doi: 10.1158/1535-7163.MCT11-0422

Uhmann, A., Niemann, H., Lammering, B., Henkel, C., Hess, I., Rosenberger, A., et al. (2012). Calcitriol inhibits Hedgehog signaling and induces vitamin D receptor signaling and differentiation in the patched mouse model of embryonal rhabdomyosarcoma. Sarcoma 2012, 357040. doi: 10.1155/2012/357040

Vink-van Wijngaarden, T., Pols, H. A. P., Buurman, C. J., Birkenhäger, J. C., and van Leeuwen, J. P. T. M. (1996). Inhibition of insulin- and insulin-like growth factorI-stimulated growth of human breast cancer cells by 1,25-dihydroxyvitamin $\mathrm{D}_{3}$ and the vitamin $\mathrm{D}_{3}$ analogue EB1089. Eur. J. Cancer 32A, 842-848. doi: 10.1016/0959-8049(95)00647-8

Wang, W. L., Chatterjee, N., Chittur, S. V., Welsh, J., and Tenniswood, M. P. (2011). Effects of $1 \alpha, 25$ dihydroxyvitamin $\mathrm{D}_{3}$ and testosterone on miRNA and mRNA expression in LNCaP cells. Mol. Cancer 10, 58. doi: 10.1186/1476-4598-10-58

Woeckel, V. J., Bruedigam, C., Koedam, M., Chiba, H., van der Eerden, B. C. J., and van Leeuwen, J. P. T. M. (2013a). 1 $\alpha, 25$-dihydroxyvitamin $\mathrm{D}_{3}$ and rosiglitazone synergistically enhance osteoblast-mediated mineralization. Gene 512, 438-443. doi: 10.1016/j.gene.2012.07.051

Woeckel, V. J., Koedam, M., van de Peppel, J., Chiba, H., van der Eerden, B. C. J., and van Leeuwen, J. P. T. M. (2012). Evidence of vitamin D and interferon- $\beta$ crosstalk in human osteoblasts with $1 \alpha, 25$-dihydroxyvitamin $\mathrm{D}_{3}$ being dominant over interferon- $\beta$ in stimulating mineralization. J. Cell. Physiol. 227, 3258-3266. doi: $10.1002 /$ jcp. 24020

Woeckel, V. J., van der Eerden, B. C. J., Schreuders-Koedam, M., Eijken, M., and Van Leeuwen, J. P. T. M. (2013b). 1 1 ,25-dihydroxyvitamin $\mathrm{D}_{3}$ stimulates activin
A production to fine-tune osteoblast-induced mineralization. J. Cell. Physiol. 228, 2167-2174. doi: 10.1002/jcp. 24388

Wu, F. S., Zheng, S. S., Wu, L. J., Teng, L. S., Ma, Z. M., Zhao, W. H., et al. (2007). Calcitriol inhibits the growth of MHCC97 heptocellular cell lines by down-modulating c-met and ERK expressions. Liver Int. 27, 700-707. doi: 10.1111/j.1478-3231.2007.01487.x

Yanagi, Y., Suzawa, M., Kawabata, M., Miyazono, K., Yanagisawa, J., and Kato, S. (1999). Positive and negative modulation of vitamin D receptor function by transforming growth factor- $\beta$ signaling through Smad proteins. J. Biol. Chem. 274, 12971-12974.

Yanagisawa, J., Yanagi, Y., Masuhiro, Y., Suzawa, M., Watanabe, M., Kashiwagi, K., et al. (1999). Convergence of transforming growth factor- $\beta$ and vitamin D signaling pathways on SMAD transcriptional coactivators. Science 283, 1317-1321.

Yu, X. P., Bellido, T., and Manolagas, S. C. (1995). Down-regulation of NF-кB protein levels in activated human lymphocytes by 1,25 -dihydroxyvitamin $\mathrm{D}_{3}$. Proc. Natl. Acad. Sci. U.S.A. 92, 10990-10994.

Yuan, W., Pan, W., Kong, J., Zheng, W., Szeto, F. L., Wong, K. E., et al. (2007). 1,25-dihydroxyvitamin $\mathrm{D}_{3}$ suppresses renin gene transcription by blocking the activity of the cyclic AMP response element in the renin gene promoter. J. Biol. Chem. 282, 29821-29830. doi: 10.1074/jbc.M7054 95200

Zhang, G. Y., Cheng, T., Luan, Q., Liao, T., Nie, C. L., Zheng, X., et al. (2011). Vitamin D: a novel therapeutic approach for keloid, an in vitro analysis. Br. J. Dermatol. 164, 729-737. doi: 10.1111/j.1365-2133.2010.10130.x

Zhao, X. Y., Ly, L. H., Peehl, D. M., and Feldman, D. (1999). Induction of androgen receptor by $1 \alpha, 25$-dihydroxyvitamin $\mathrm{D}_{3}$ and 9-cis retinoic acid in LNCaP human prostate cancer cells. Endocrinology 140, 1205-1212. doi: 10.1210/endo.140.3.6561

Conflict of Interest Statement: The authors declare that the research was conducted in the absence of any commercial or financial relationships that could be construed as a potential conflict of interest.

Received: 10 January 2014; paper pending published: 21 January 2014; accepted: 30 January 2014; published online: 18 February 2014.

Citation: Larriba MJ, González-Sancho JM, Bonilla F and Muñoz A (2014) Interaction of vitamin D with membrane-based signaling pathways. Front. Physiol. 5:60. doi: 10.3389/fphys.2014.00060

This article was submitted to Integrative Physiology, a section of the journal Frontiers in Physiology.

Copyright (c) 2014 Larriba, González-Sancho, Bonilla and Muñoz. This is an openaccess article distributed under the terms of the Creative Commons Attribution License (CC BY). The use, distribution or reproduction in other forums is permitted, provided the original author(s) or licensor are credited and that the original publication in this journal is cited, in accordance with accepted academic practice. No use, distribution or reproduction is permitted which does not comply with these terms. 